\title{
Curriculum Guideline for Masters Real Estate Education in South Africa
}

\author{
Dr. Samuel H.P. Chikafalimani \\ Property Valuer / Property Industry Specialist \\ Industrial Development Corporation of South Africa \\ E-mail: samuelc@idc.co.za
}

Doi:10.5901/ajis.2013.v2n3p397

\begin{abstract}
As part of the process of assessment of Masters Real Estate (MRE) curricula in South Africa, real estate professionals in the property industry were surveyed to rank topics included in the curricula in order of their importance. Results reveal that professionals consider Property Finance as the most important topic in the curriculum and Information Technology as the least important topic. Findings will guide universities offering MRE programmes in South Africa and elsewhere in the processes of curriculum improvement.
\end{abstract}

Keywords: Curriculum, real estate topics, property industry

\section{Introduction}

Masters Real Estate programmes taught by coursework which are offered in South Africa are contained in Table 1. As part of the process of assessment of these curricula, real estate professionals in the property industry in South Africa were surveyed to obtain views on the importance of topics included in the curricula. Justification for the study is based on the fact that postgraduate real estate curricula in South Africa were developed without conducting more detailed property industry surveys to determine curriculum requirements (Cloete, 2002; and Chikafalimani and Cloete, 2007). Therefore, this study directly links actual industry requirements with the curriculum. In addition, practitioners in the industry have an important role to play in the process of real estate curriculum improvement since they have the experience and are familiar with the requirements to enable real estate professionals practice competently in the industry (Galuppo and Worzala, 2004). They also employ students graduating from the real estate programmes. Based on this they are well positioned to support educators in the processes of curriculum review and improvement (Callanan and McCarthy, 2003).

\section{Literature review}

This study aims at providing a curriculum guideline for MRE education in South Africa by asking real estate professionals in the industry importance of topics included in the existing curricula. The intention of the study is to demonstrate to universities offering the curricula on how a real estate curriculum can be developed to meet property industry requirements. Unfortunately, few authors have investigated the importance of real estate topics in a curriculum. Brown (1979) conducted a survey to determine a consensus on the importance of real estate topics included in a university undergraduate real estate curriculum among professors and real estate professionals in the USA. Results of the study show that professionals view the importance of topics offered in the curricula differently from professors. An attempt to identify important real estate topics from an international perspective was undertaken by Black and Rabianski (1999) by surveying real estate academics and practitioners outside the USA and Canada. Their research results reveal that there is a divergence of opinion on a list of important topics and the importance of each topic. This divergence is related to the respondents' primary area of interest in real estate and geographic area.

Table 1: Masters Real Estate programmes offered in South Africa

\begin{tabular}{|l|c|c|c|c|c|}
\hline \multicolumn{1}{|c|}{ University \& Dept / School } & $\begin{array}{c}\text { Name of } \\
\text { degree }\end{array}$ & Admission requirements & Duration & Delivery & $\begin{array}{c}\text { Total } \\
\text { credits }\end{array}$ \\
\hline $\begin{array}{l}\text { Pretoria } \\
\text { (Construction Economics) }\end{array}$ & MSRE & $\begin{array}{c}\text {.Hons, } 4 \text { or } 5 \text { yr relevant } \\
\text { bachelors degree } \\
\text {.Work experience }\end{array}$ & 2 yrs \& treatise & 8 block weeks & 180 \\
\hline
\end{tabular}




\begin{tabular}{|c|c|c|c|c|c|}
\hline $\begin{array}{l}\text { Witwatersrand } \\
\text { (Construction Economics \& } \\
\text { Management) }\end{array}$ & MSPDM & $\begin{array}{c}\text {.Relevant good bachelors } \\
\text { degree } \\
\text { Work experience }\end{array}$ & $\begin{array}{l}1 \text { yr full time, } 2 \text { yrs part } \\
\text { time \& treatise }\end{array}$ & $\begin{array}{l}1 \text { week block } \\
\text { release }\end{array}$ & 240 \\
\hline $\begin{array}{l}\text { Cape Town } \\
\text { (Construction Economics \& } \\
\text { Management) }\end{array}$ & MSPS & $\begin{array}{c}\text { Hons or } 4 \text { yr relevant } \\
\text { bachelors degree } \\
\text {.Work experience }\end{array}$ & 2 yrs \& treatise & Block system & 200 \\
\hline $\begin{array}{l}\text { Free State } \\
\text { (Quantity Surveying \& } \\
\text { Construction Management) }\end{array}$ & MPS & $\begin{array}{l}\text { Relevant good bachelors } \\
\text { degree }\end{array}$ & 2 yrs \& treatise & $\begin{array}{l}8 \text { workshop } \\
\text { weeks }\end{array}$ & 200 \\
\hline $\begin{array}{l}\text { Nelson Mandela Metropolitan } \\
\text { (Construction Management \& } \\
\text { Quantity Surveying) }\end{array}$ & MSBE & $\begin{array}{c}\text { Relevant good bachelors } \\
\text { degree } \\
\text { Work experience } \\
\end{array}$ & $\begin{array}{l}1 \text { yr full time, } 2 \text { yrs part } \\
\text { time \& treatise }\end{array}$ & $\begin{array}{l}4 \text { or } 5 \text { block } \\
\text { weeks }\end{array}$ & 202 \\
\hline \multicolumn{6}{|c|}{$\begin{array}{l}\text { Key: } \\
\text { MSRE: Master of Science in Real Estate } \\
\text { MSPDM: Master of Science in Property Development and Management } \\
\text { MSPS: Master of Science in Property Studies } \\
\text { MPS: Masters in Property Science } \\
\text { MSBE: Master of Science in Built Environment }\end{array}$} \\
\hline
\end{tabular}

Sources: Real Estate Study Guides Universities of Pretoria, Witwatersrand, Free State, Cape Town, and Nelson Mandela Metropolitan (2013)

Other educators and researchers including Chambers, Holms, and Worzala (2009) have emphasized the involvement of the industry in the assessment of the curricula to identify important topics for the industry. In response Ooi and Yu (2011) and Jayantha and Chiang (2012) surveyed real estate professionals in the property industries in Singapore and Hong Kong; respectively. In these recent studies real estate professionals considered Property Finance as more important topic than other topics in real estate curriculum.

Epley (1996) completed a two-year study of the current state of body of knowledge of real estate requested by the Board of Directors of the American Real Estate Society (ARES). After the survey of ARES academic membership and available publications, he observes that various real estate curriculum paradigms exist. As a result he concludes that today there is no consensus among educators about important topics to be included in a real estate curriculum. However, Epley (1996) recommended that further research be undertaken to discover important topics included in different real estate curricula as part of the effort to establish real estate body of knowledge. This study attempts to partially address this request by asking real estate professionals on their view of the importance of topics included in MRE curricula in South Africa. The intention is to guide the universities offering the curricula in the processes of real estate curriculum development and improvement in order to continuously meet property industry requirements.

\section{Research Methodology}

To obtain views of importance on topics in MRE curricula from the industry, a questionnaire was administered. Real estate professionals were assisted to rank the topics in order of importance by using the Lickert Scale where 1 is equivalent to 'Not Important', 2 is equivalent to 'Important', and 3 is equivalent to 'Very Important'. The questionnaire was sent to 777 real estate professionals; 748 of these were delegates who attended South African Property Owners Association (SAPOA) International Convention and 29 were first and second year students who enrolled for the Master of Science in Real Estate at the University of Pretoria in South Africa. Out of 777 questionnaires which were sent out, a total of 250 questionnaires were returned, representing $32.18 \%$ response rate. The SAPOA members and delegates were used in the property industry survey because SAPOA is the main representative body and official voice of leading property owners and investors in South Africa, and delegates came from both the private and public sectors of the property industry. SAPOA members also comprised of real estate professionals from different real estate fields and geographical areas in South Africa. This was of great benefit to the survey because it minimised biases. MSc (Real Estate) students studying at the University of Pretoria were included in the property industry survey because most of them are working and know what is expected at the workplace.

Table 2 shows the description of statistics of respondents to the survey. By qualification, $86.4 \%$ of the respondents had formal university education. With regard to work experience, $23 \%$ were recent graduates with 0 to 5 years of experience. Topic comments from this category were based on recent university real estate course content. Respondents with 6 to 15 years work experience were the largest cohort group representing 41.2\% while those with 16 years or more 
of experience represented $35.2 \%$ of respondents. The last two categories are considered more experienced and are employers or mentors of the recent graduates. Geographically, statistics show that all provinces in South Africa were represented by respondents in the survey. In addition, $5.6 \%$ of the respondents operated internationally, confirming that real estate business was indeed growing and gaining importance globally (Roulac, 2002; and Schulte and SchulteDaxboek, 2003).

\section{Results and analysis}

\subsection{Overall response on importance of Masters Real Estate topics by all respondents}

Table 3 shows overall rating of the topics by real estate professionals using the mean. The highest mean is 2.77 for Property Finance and the lowest mean is 1.88 for Information Technology which is almost 2. Based on this overall rating, it is observed that real estate professionals consider all eighteen topics included in MRE curricula to be important for the property industry in South Africa. No topic scored 3 and none scored 1.

\subsection{Ranking of importance of Masters Real Estate topics by all respondents}

Ranking of the eighteen topics in order of their importance by all real estate professionals by descending mean is given in Table 3. In terms of topic importance, the respondents ranked Property Finance as number one with a mean of 2.77, Property Investment was ranked second with a mean of 2.67, Property Economics was ranked third with a mean of 2.66, and Property Development was ranked fourth with a mean of 2.65. Ranked at the bottom are the following topics: International Real Estate with a mean of 1.92 and Information Technology with a mean of 1.88. The results show that real estate practitioners regard Property Finance as the most important topic and Information Technology as least important topic in MRE curriculum.

Table 2: Description of statistics of survey respondents

\begin{tabular}{|l|c|c|}
\hline \multicolumn{1}{|c|}{ Qualification } & Frequency & Percentage (\%) \\
\hline Matric & & \\
\hline Bachelor's degree & 19 & 7.6 \\
\hline Honour's degree & 77 & 30.8 \\
\hline Master's degree & 66 & 26.4 \\
\hline Doctorate degree & 70 & 28 \\
\hline Other & 3 & 1.2 \\
\hline Total & 15 & 6 \\
\hline \multicolumn{1}{|c|}{ Current property industry involvement ${ }^{1}$} & 250 & 100 \\
\hline Academic / trainer & & \\
\hline Property Developer & 22 & 5.5 \\
\hline Property Valuer & 80 & 19.8 \\
\hline Property / Facilities Manager & 37 & 9.2 \\
\hline Property Investor & 72 & 17.8 \\
\hline Property Broker / Marketer & 48 & 11.9 \\
\hline Property Finance & 35 & 8.7 \\
\hline Property Economist & 55 & 13.6 \\
\hline Building Contractor & 6 & 1.5 \\
\hline Other & 11 & 2.7 \\
\hline Total & 38 & 9.4 \\
\hline \multicolumn{1}{|c|}{ Category of years of experience } & 404 & 100 \\
\hline 0 to 5 years & 59 & 23.6 \\
\hline 6 to 15 years & 103 & 41.2 \\
\hline 16 to 42 years & 88 & 35.2 \\
\hline Total & 250 & 100 \\
\hline & & \\
\hline Gauteng & 138 & 55.2 \\
\hline Northern Cape & 1 & 0.4 \\
\hline
\end{tabular}




\begin{tabular}{|c|c|c|}
\hline KwaZulu-Natal & 27 & 10.8 \\
\hline Eastern Cape & 5 & 2 \\
\hline Mpumalanga & 3 & 1.2 \\
\hline Western Cape & 27 & 10.8 \\
\hline Free State & 2 & 0.8 \\
\hline National & 33 & 13.2 \\
\hline International & 14 & 5.6 \\
\hline Total & 250 & 100 \\
\hline
\end{tabular}

\subsection{Rating of importance of Masters Real Estate topics based on years of experience}

Table 4 shows rating of the importance of MRE topics by category of years of experience using the mode where 1 represents 'Not Important', 2 represents 'Important', and 3 represents 'Very Important'. Results in Table 4 reveal two interesting issues. Firstly, professionals with 0 to 5 year work experience have indicated that Information Technology as a topic is not important in MRE curriculum by rating it 1 . The reason for this rating could be that real estate professionals in this category are generally younger and started to attend school in an era when Information Technology is being emphasised and taught even at lower levels of education. Secondly, professionals with 16 to 42 years of work experience have rated International Real Estate as not important topic in the curriculum by assigning it 1.The reason for this rating could be that real estate professionals in this work experience category are generally older and studied as well as started practising in an era when influences of globilisation were not so critical on real estate business and education as compared to the way it is now in the $21^{\text {st }}$ Century.

Table 3: Ranking of Masters Real Estate topics by real estate professionals based on importance

\begin{tabular}{|l|c|c|}
\hline \multicolumn{1}{|c|}{ Topic } & Rank & Mean \\
\hline Property Finance & 1 & 2.76707 \\
\hline Property Investment & 2 & 2.67470 \\
\hline Property Economics & 3 & 2.66265 \\
\hline Property Development & 4 & 2.64659 \\
\hline Financial Management & 5 & 2.56225 \\
\hline Property Valuation & 6 & 2.51004 \\
\hline Property Law & 7 & 2.47791 \\
\hline Building Economics & 8 & 2.37349 \\
\hline Property Management / Facilities Management & 9 & 2.31727 \\
\hline Property Tax & 10 & 2.27711 \\
\hline Construction Contract Law & 11 & 2.16867 \\
\hline Property Marketing & 12 & 2.16064 \\
\hline Research & 13 & 2.10843 \\
\hline Environmental Economics \& Management & 14 & 2.00803 \\
\hline Building Technology & 15 & 1.94378 \\
\hline Corporate Strategy & 16 & 1.91968 \\
\hline International Real Estate & 17 & 1.91566 \\
\hline Information Technology & 18 & 1.88353 \\
\hline
\end{tabular}

Table 4: Rating of importance of Masters Real Estate topics by category of years of experience

\begin{tabular}{|l|c|c|c|c|c|}
\hline \multicolumn{1}{|c|}{ Topic } & \multicolumn{3}{c|}{ Mode } & \\
\hline \multicolumn{1}{|c|}{} & $\mathbf{0 - 5}$ years & $\mathbf{6 - 1 5}$ years & $\mathbf{1 6 - 4 2}$ years & P-Value & Significance level \\
\hline Building Economics & 3 & 3 & 3 & 0.3265 & $\mathrm{nsl}$ \\
\hline Building Technology & 2 & 2 & 2 & 0.8626 & $\mathrm{nsl}$ \\
\hline Construction Contract Law & 3 & 2 & 2 & 0.0164 & $\mathrm{sl}$ \\
\hline Corporate Strategy & 2 & 2 & 2 & 0.2744 & $\mathrm{nsl}$ \\
\hline Environmental Economics \& Management & 2 & 2 & 2 & 0.4262 & $\mathrm{nsl}$ \\
\hline Financial Management & 3 & 3 & 3 & 0.7925 & $\mathrm{nsl}$ \\
\hline Information Technology & 1 & 2 & 2 & 0.1138 & $\mathrm{nsl}$ \\
\hline International Real Estate & 2 & 2 & 1 & 0.0013 & $\mathrm{sl}$ \\
\hline Property Development & 3 & 3 & 3 & 0.7701 & $\mathrm{nsl}$ \\
\hline
\end{tabular}




\begin{tabular}{|l|c|c|c|c|c|}
\hline Property Economics & 3 & 3 & 3 & 0.1860 & $\mathrm{nsl}$ \\
\hline Property Finance & 3 & 3 & 3 & 0.9668 & $\mathrm{nsl}$ \\
\hline Property Investment & 3 & 3 & 3 & 0.3378 & $\mathrm{nsl}$ \\
\hline Property Management / Facilities Management & 3 & 3 & 2 & 0.2208 & $\mathrm{nsl}$ \\
\hline Property Marketing & 2 & 2 & 2 & 0.4031 & $\mathrm{nsl}$ \\
\hline Property Law & 3 & 3 & 2 & 0.0141 & $\mathrm{sl}$ \\
\hline Property Valuation & 3 & 3 & 3 & 0.1856 & $\mathrm{nsl}$ \\
\hline Property Tax & 3 & 2 & 2 & 0.0016 & $\mathrm{sl}$ \\
\hline Research & 2 & 2 & 2 & 0.1994 & $\mathrm{nsl}$ \\
\hline
\end{tabular}

Chi-Square tests were conducted on the three categories of years of experience ( 0 to 5 years, 6 to 15 years, and 16 to 42 years) for each topic to compare if there are relationships between importance of topics and years of experience. The test was conducted at $5 \%$ level of significance. Table 4 shows that only four topics out of eighteen topics (22.2\%) had significant relationships between importance of topic and years of experience. This result indicates that despite the differences in years of experience, there are no serious differences among real estate practitioners on the ranking of importance of topics as given in Table 3.

\subsection{Rating of importance of Masters Real Estate topics based on geographical location}

In order to conduct a meaningful test to test for relationship between importance of topics and geographical location, the respondents were divided into five geographical locations. These regions are described as Cape, Transvaal, KwaZuluNatal and Free State, National, and International. Cape region combined respondents from Northern Cape, Eastern Cape and Western Cape Provinces. Respondents from Gauteng, Limpopo, North West, and Mpumalanga Provinces were grouped together to form Transvaal region. The third geographical location combined respondents from KwaZulu-Natal and Free State. The fourth geographical region was National. This location included all respondents who operated in more than one of the four geographical locations. The last geographical location was International and included all respondents who also operated outside South Africa.

Table 5 shows rating of the importance of MRE topics by geographical location using the mode where 1 represents 'Not Important', 2 represents 'Important', and 3 represents 'Very Important'. Chi-Square tests were conducted on the five geographical locations (Cape, Transvaal, KwaZulu-Natal and Free State, National, and International) for each topic to test if there were relationships between importance of topics and geographical location. The test was conducted at $5 \%$ level of significance. Table 5 shows that only two topics out of eighteen topics (11.1\%) had significant relationships between importance of topic and geographical location. These two topics are: Construction Contract Law and International Real Estate. For the other topics there were no significant relationships between importance of topic and geographical location. This result shows that despite the differences of geographical locations, there are no serious differences among real estate practitioners on the ranking of importance of topics as shown in Table 3.

Table 5: Rating of the importance of Masters Real Estate topics by geographical location

\begin{tabular}{|c|c|c|c|c|c|c|c|}
\hline & \multicolumn{5}{|c|}{ Mode } & & \\
\hline Topic & C & $\mathrm{T}$ & $\mathrm{KN}+\mathrm{FS}$ & $\mathrm{N}$ & I & P-Value & Significance level \\
\hline Building Economics & 3 & 3 & 2 & 2 & 3 & 0.7018 & nsl \\
\hline Building Technology & 1 & 2 & 2 & 1 & 2 & 0.2679 & $\mathrm{nsl}$ \\
\hline Construction Contract Law & 2 & 2 & 1 & 2 & 2 & 0.0372 & sl \\
\hline Corporate Strategy & 1 & 2 & 2 & 1 & 2 & 0.7247 & nsl \\
\hline Environmental Economics \& Management & 2 & 2 & 2 & 2 & 2 & 0.9082 & nsl \\
\hline Financial Management & 3 & 3 & 3 & 3 & 3 & 0.9343 & nsl \\
\hline Information Technology & 2 & 2 & 1 & 1 & 1 & 0.7427 & nsl \\
\hline International Real Estate & 1 & 2 & 2 & 1 & 2 & 0.0150 & sl \\
\hline Property Development & 3 & 3 & 3 & 3 & 3 & 0.7957 & nsl \\
\hline Property Economics & 3 & 3 & 3 & 3 & 3 & 0.6179 & nsl \\
\hline Property Finance & 3 & 3 & 3 & 3 & 3 & 0.9029 & nsl \\
\hline Property Investment & 3 & 3 & 3 & 3 & 3 & 0.7334 & $\mathrm{nsl}$ \\
\hline Property Management/ Facilities Management & 3 & 2 & 3 & 2 & 3 & 0.3606 & nsl \\
\hline Property Marketing & 2 & 2 & 2 & 2 & 3 & 0.4041 & nsl \\
\hline
\end{tabular}




\begin{tabular}{|l|l|l|l|l|l|l|c|}
\hline Property Law & 2 & 3 & 3 & 3 & 3 & 0.6117 & nsl \\
\hline Property Valuation & 3 & 3 & 3 & 3 & 3 & 0.6300 & nsl \\
\hline Property Tax & 2 & 2 & 2 & 2 & 2 & 0.7009 & nsl \\
\hline Research & 2 & 2 & 2 & 2 & 3 & 0.1191 & nsl \\
\hline Key: C = Cape. T = Transvaal. KN = KwaZulu-Natal. FS = Free State. N = National. I = International \\
P-Value: Probability of significant difference. nsl: No significant relationship. sl: significant relationship \\
\hline
\end{tabular}

\section{Conclusion}

Results of the survey show that topics included in the existing MRE curricula in South Africa and other parts of the world are important for the property industry in South Africa. This is proven based on the fact that real estate professionals rated all topics as important for the industry. The impression given by the practitioners is that real estate should be viewed broadly, and for graduates to function competently in the industry they need to be exposed to different topics relevant to proper understanding of real estate. Therefore, real estate professionals in South Africa are in favour of the interdisciplinary approach to the study of real estate. However, results from topic rankings reveal that real estate professionals consider Property Finance as the most important topic; hence emphasis must be placed on Property Finance than other topics in the curriculum. These findings are a good guideline in the processes of curriculum development and improvement for universities offering MRE programmes in South Africa and elsewhere in order to meet property industry requirements in the future.

\section{References}

Black, R.T., and Rabianski, J.S. (1999). An International perspective on the importance of real estate concepts and topics, Journal of Real Estate Practice and Education, Vol. 2 No.1, pp. 13-32.

Brown, J.R. Jr. (1979). Real estate education: a curriculum guideline, Appraisal Journal, pp. 574-586.

Callanan, J., and McCarthy, I. (2003). Property education in New Zealand: Industry requirements and student perceptions, Journal of Real Estate Practice and Education, Vol. 6 No.1, pp. 23-32.

Chambers, L., J. Holms, and Worzala, E. (2009). Graduate real estate education: Integrating the industry, International Journal of Property Studies, 1.

Chikafalimani, S.H.P. and Cloete, C.E. (2007). A critical assessment of postgraduate real estate education in South Africa: Importance and research approach, paper presented at the Association of Schools of Construction of Southern Africa - $2^{\text {nd }}$ Built Environment Conference, 17-19 June 2007, Port Elizabeth, South Africa.

Cloete, C.E. (2002). Progress in real estate education in South Africa, Journal of Property Management, Vol.20 No.5, pp. 369-382.

Epley, D.R. (1996). The current body of knowledge paradigms used in real estate education and issues in need of further research, Journal of Real Estate Research, Vol. 12 No.2, pp 229-236.

Galuppo, L.A. and Worzala, E. (2004). A study into the important elements of Masters Degree in Real Estate, Journal of Real Estate Practice and Education, Vol. 7 No.1, pp 25-42.

Jayantha, W.M. and Chiang, Y.H. (2012). Key elements of successful graduate real estate education in Hong Kong, Journal of Real Estate Practice and Education, Vol. 15 No.2, pp 101-110.

Nelson Mandela Metro University, Department of Construction Management and Quantity Surverying, Masters of Science in the Built Enviroment Study Guide (2013).

Roulac, S.E. (2002). Requisite knowledge for effective property involvements in the global context. In monograph of Real Estate Education Throghout the World: Past, Present and Future. Schulte K.-W. (editor). Academic Publishers.

Schulte K.-W. and Schulte-Daxboek, G. (2003). Internationalisation of real estate education, paper presented at thePacific Rim Real Estate Society Conference, Brisbane, Australia, 19-22 January, 2003

Ooi, J.T.L. and Yu, S. (2011). Graduate real estate education in Singapore: What prospective students look for, Journal of Real Estate Practice and Education, Vol.14 No.1, pp 35-52.

University of Cape Town, Department of Construction Economics and Management, Property Studies Guide (2013).

University of Free State, Department of Quantity Surveying and Construction Management, Master in Property Science Bronchure (2013).

University of Pretoria, Department of Construction Economics, Real Estate Study Guides (2013).

University of Witwatersrand, School of Construction Economics and Management, Postgraduate Handbook (2013). 